\title{
Changes and continuities in agricultural work: the case of small and medium-sized vineyards in Mendoza, Argentina
}

\author{
María Brignardello, ${ }^{1,2, *}$ \\ ${ }^{1}$ Centro de Estudios e Investigaciones Laborales CEIL CONICET, Saavedra 15, 4 floor, Buenos Aires, Argentina \\ ${ }^{2}$ Universidad del Salvador USAL, Facultad de Ciencias Sociales, Tte. Gral. Juan Domingo Perón 1818, Buenos Aires, Argentina
}

\begin{abstract}
To examine today's agricultural production processes requires redefining work and the social agents involved in it. As such, this article belongs to the scholarly literature that seeks to understand how the emphasis on quality in the agricultural industry reshapes agricultural work at the local level. In particular, it aims to explore the implications of these structural changes for small and medium-sized vineyards. Since the late 1980s, the wine grape industry in the Argentine province of Mendoza has experienced structural changes. This process has been referred to as a "quality turn". As a result, small and medium-sized vineyards must alter their practices. In this context, our questions include the following: what does this mean for labor in these vineyards? Who performs the newly required tasks, as well as the traditional ones? We address these questions through a qualitative analysis of interviews with the winegrape growers of small and mediumsized vineyards located in the High Mendoza River Area (Argentina). Using this methodology, we strive to understand the current forms of labor organization in an agricultural sector influenced by both global changes and local history. In conclusion, we argue that the labor practices and power structure between the winegrape grower, his family, and non-family workers are not uniform across all vineyards. Instead, we find great diversity in the organization and operation of small and medium-sized vineyards.
\end{abstract}

Keywords: quality turn / grape production / small and medium-sized vineyards / labor

Résumé - Continuités et changements dans le travail agricole : le cas des petits et moyens vignobles à Mendoza, Argentine. L'examen des processus actuels de production en agriculture demande une redéfinition du travail et des agents sociaux qui y sont impliqués. Cet article s'inscrit dans les études qui cherchent à comprendre comment la recherche de qualité dans l'agro-industrie remodèle le travail agricole au niveau local. Depuis la fin des années 1980, des changements structurels importants se sont produits dans la production viticole à Mendoza. Le secteur de la production de vin de qualité a mis l'accent sur le développement de produits différenciés, en réponse à la croissance des exportations, tout en maintenant la demande du marché intérieur. La petite et moyenne production viticole, qui traverse ces processus de restructuration, doit réadapter ses liens avec l'agro-industrie et ses pratiques productives aux nouvelles demandes. Quelles conséquences pour le travail agricole dans la vigne? Qui assume les nouvelles tâches agricoles à intégrer et les tâches traditionnelles? Pour répondre à ces questions, nous avons effectué une analyse qualitative d'entretiens menés auprès de petits et moyens producteurs situés dans la zone amont de la rivière Mendoza. L'objectif est de comprendre les formes actuelles d'organisation du travail dans un secteur agricole marqué par des changements globaux, mais aussi par l'histoire locale. En conclusion, les liens établis dans l'espace de travail entre le producteur, sa famille et les travailleurs non familiaux varient d'un vignoble à l'autre et ne sont pas fixés une fois pour toutes. Il existe une grande diversité de formes d'organisation du travail dans la petite et moyenne production de vin de qualité.

Mots clés: : viticulture de qualité / production de raisin / petits et moyens producteurs / travail

*Corresponding author: maria.brignardello@gmail.com 


\section{Introduction}

The global agricultural system has undergone drastic restructuring processes in recent decades. These changes have important consequences for agri-food production and social agents at the local level (Bonanno and Cavalcanti, 2011; Buttel, 1997; Friedmann, 1980; Trienekens, 2011). In this article, we examine these implications by focusing specifically on small and medium-sized vineyards in the Argentine province of Mendoza.

Since the late 1980 s, a number of changes have occurred in the wine industry in Mendoza. This sector experienced what has been referred to as a "quality turn" (Goodman, 2003), which is a mechanism for product differentiation (Henson and Humphrey, 2010). More specifically, part of this agroindustrial sector has become reoriented toward a higher degree of varietal specialization - especially Malbec-, as well as exporting. That being said, these reconfigurations do not necessarily involve codification, new certification requirements, third-party certification, nor the enforcement of regulations based on formal quality standards (Biénabe et al., 2011; Henson and Humphrey, 2010).

Within this scenario, the small and medium-sized vineyards that manage to restructure themselves around this turn to quality must alter their relationships with other actors in the agro-industry, specifically wineries, and their production practices (Brignardello, 2012). The question is, then, who performs the new tasks associated with this quality turn, and who performs the traditional labor tasks established prior to the implementation of this shift?

In this piece, we first document the labor changes that have occurred due to overall agricultural restructuring. Next, we outline those associated with the quality turn. Then, we present the case study. Subsequently, we analyze the ways in which small and medium-sized vineyards organize agricultural work, taking into account the impact of the quality conventions on their operations. We focus on family and non-family agricultural workers, in particular. Finally, we conclude with some considerations regarding labor relations in a locally restructured agricultural industry.

\section{Reconfigurations in the organization of agricultural labor}

The structural changes in the global agri-food system have had economic, political, and social implications for local agricultural production. Scholars have voiced many concerns about these changes. Among these concerns are the role of trade liberalization in the agricultural and food order (Ufkes, 1993); foreign and direct investment in food production, processing and retail; increasing levels of vertical coordination (Maertens and Swinnen, 2015); and different political actions that frame these processes (McDermott, 2007).

Additionally, there has been a great increase in public and private food safety and quality standards in agriculture (Hervieu, 1996; Henson and Humphrey, 2010). Consequently, companies and producers have to adapt their practices to meet these requirements (Trienekens and Zuurbier, 2008). Wine regions have been particularly affected by these transformations (González and Parga-Dans, 2017; Raftery, 2017) due to the fact that they serve a global market and receive high levels of international investment (Overton et al., 2012).

Overall, these global restructuring processes have modified the ways in which agricultural work is done and, relatedly, the roles of the social agents associated with it (Buttel, 1997). However, the scope of this impact varies depending on factors such as local labor regulatory frameworks, requirements for meeting quality standards, etc. (Friedmann, 1980). Additionally, this restructuring does not completely overhaul agricultural practices, since as we mentioned earlier, this quality turn does not always entail the enforcement of formal regulations for complying with quality preferences. Rather, traditional practices are combined with new ones and sometimes, practices that were previously considered to be secondary become primary (Bocco and Neiman, 2001; Marsden, 1997). In this article, the agricultural production process is understood to be comprised of social labor relations (Marsden et al., 1996).

Historically, the agricultural industry has been characterized by high levels of labor informality and precariousness, as well as by more personal employment relations than any other labor sector (Newby, 1983). Its workforce has also been perceived to be unskilled and indistinguishable. Today, however, these long-standing characteristics and perceptions are being called into question due to the increasing use of technological innovations in agriculture (Bendini and Pescio, 1996).

Specifically, family farming has experienced changes in its mode of operation and labor configuration (Neiman, 2010). In order to cut costs and simplify workforce management, the amount of work performed by family members has declined and been partially replaced by outsourced labor and that of hired workers (Craviotti, 2000). Furthermore, it is argued that the farmer's own role has changed. Although he continues to participate in the farm's operation, he now plays more of a managerial role (Craviotti, 2000; Gras and Hernández, 2009). Management style is not uniform, however, and can vary between farmers (Alvaro, 2012).

Farming by non-family members has also undergone changes due to this quality turn, thus modifying the profile of the non-family worker. However, this does not necessarily translate into different levels of monetary compensation for these workers (Quaranta, 2003). Additionally, the quality turn and labor market segmentation are factors impacting these laborers, causing their positions to be even more unstable and precarious (Bonanno and Cavalcanti, 2011; Lara Flores, 1998; Long, 1996; Pedreño, 1999).

\section{Methodology and presentation of the case study}

In order to address our research questions regarding recent changes and continuities in agricultural work, we designed a mixed methods case study analysis, with qualitative methods being primary. We conducted semi-structured interviews with the winegrape growers of 24 small and medium-sized vineyards. Our case selection was based on the following criteria: the winegrape grower worked in the vineyard, whether performing manual work or management and administration tasks; the winegrape grower could recruit non-family members as workers on a permanent basis; the vineyard did not exceed 


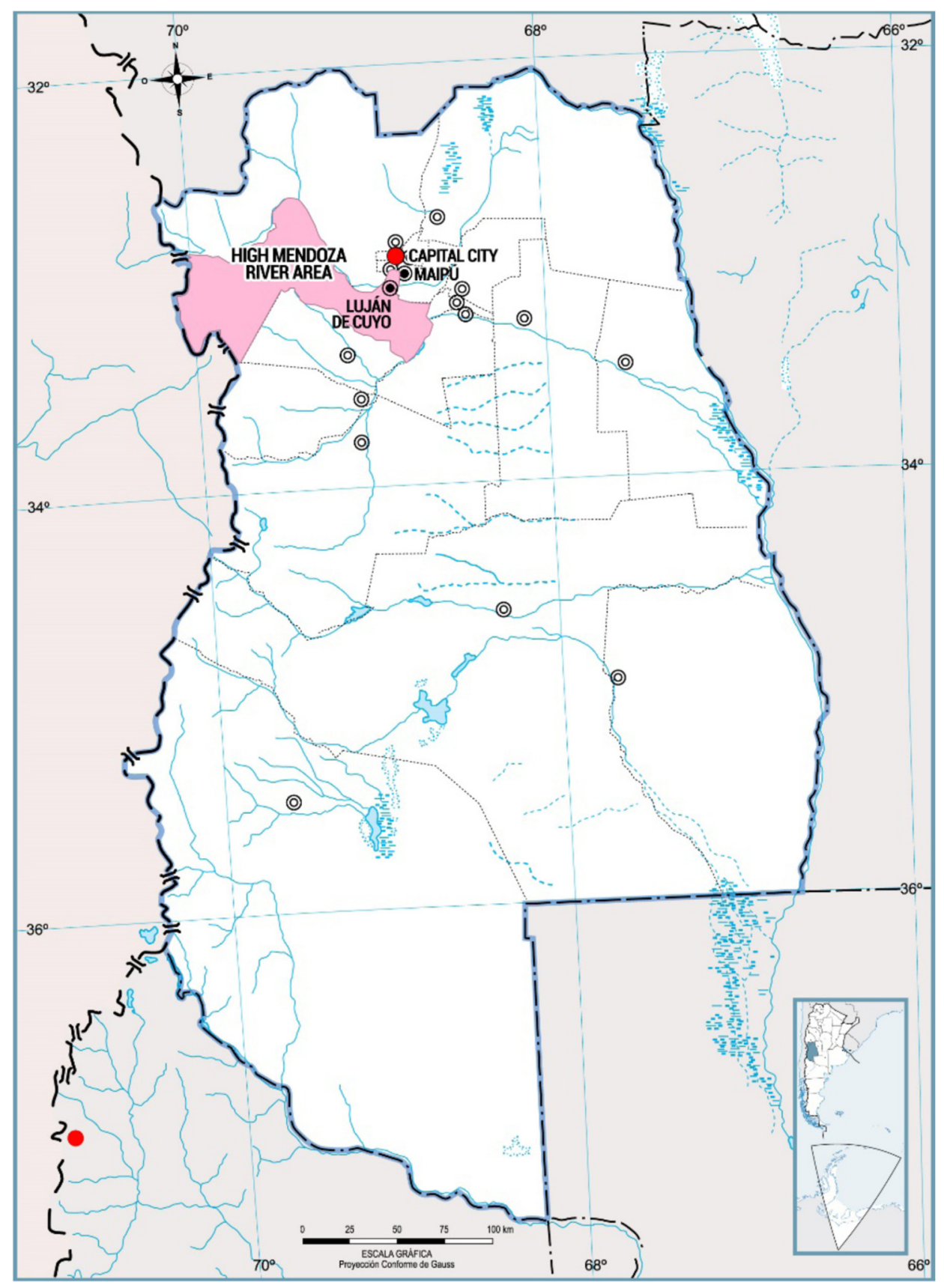

Fig. 1. High Mendoza River Area in the province of Mendoza. Source: Virtual Map Library.

Fig. 1. Zone amont de la rivière Mendoza, dans la province de Mendoza.

25 hectares in size; the vineyard was located in the High Mendoza River Area, which includes two departments: Luján de Cuyo and Maipú (Fig. 1); the grower's main fruit crop was grapes, although there could be other crops in the farming area, as well; and the wine grape varieties were primarily of high enological quality, according to the National Institute for Viticulture (abbreviated as "INV" in Spanish). This last criterion was chosen because grape variety is an essential part of the local quality turn.

Until the 1980 s, this local wine industry was known for its massive production of cheap table wine for national consumption. The industry's social structure was comprised of large integrated wineries, "trasladistas" (i.e., wine cellars that sold their wine in bulk), winemaking cooperatives, and small and medium-sized vineyards (Richard Jorba, 2003).

In terms of labor market, there was a large number of permanent workers, in both vineyards and wineries, with unstable working conditions. There were also temporary workers hired for the grape harvest season. Additionally, it is important to mention the role of the vineyard contractor in Mendoza's wine grape industry (locally known as the "contratista de viña"), which was a position established through specific legislation (Law 23.154, 1984). The contractor was responsible for the vineyard's care from the beginning 


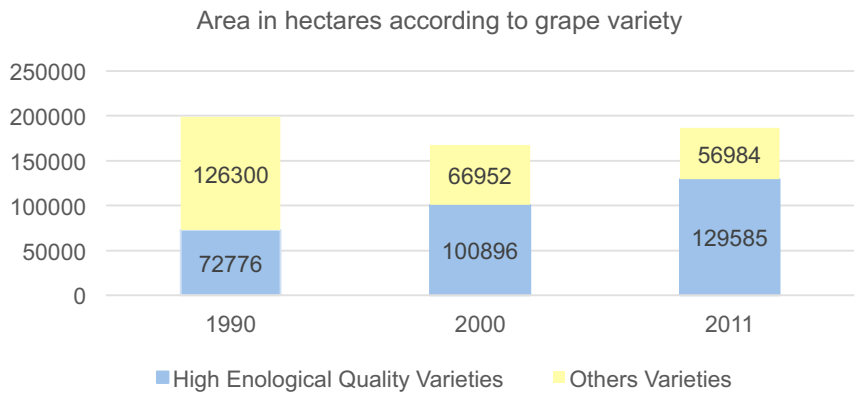

Fig. 2. Area in hectares according to grape variety in Mendoza in 1990, 2000 and 2011. Source: self-elaboration based on INV (2016) data 1990-2000-2011.

Fig. 2. Superficie (en hectares) des cépages à Mendoza, en 1990, 2000 et 2011

of the grape growth cycle through its harvest. As part of the deal, he was provided a house on the vineyard's property in which to live with his family. This situation created a strong link between the contractor's work and home lives (Poblete, 2012). As such, his family members often helped with certain tasks in the vineyard, such as pruning. In terms of monetary compensation, the contractor received a fixed salary for 10 months, which varied in amount according to the vineyard's size. During the harvest season, he earned additional income, ranging from $15 \%$ to $18 \%$ of the profits that the owner made from selling the harvested grapes to the wineries.

Throughout the first half of the twentieth century, various economic crises occurred, mainly due to overproduction. By the end of the 1980s, in the context of neoliberal economic and social policies, an irreversible crisis took place that caused this longstanding agroindustry to transform its farming practices (Azpiazu and Basualdo, 2001; Collado, 2006; Maclaine Pont and Thomas, 2007). New emphasis was placed on quality, mainly as a response to an increasing foreign demand for wine, and this led to product differentiation (Bocco and Neiman, 2001; Neiman, 2003). These changes were evident in the grape variety structure (Fig. 2), as well as in the emergence of new international markets for local wine. At the same time, other factors contributed to this reconfiguration, including changes in national wine consumption; the inflow of new actors, primarily transnational investors and large national financial groups (Heredia and Poblete, 2013); technological innovations such as stainless steel tanks; and organizational restructuring of wineries (Maclaine Pont and Thomas, 2007).

Moreover, the vineyard labor market was affected by this quality turn (Poblete, 2013). The adoption of new technologies to satisfy these expectations for certain quality implied a decrease in the need for unskilled and permanent workers; an increase of mid-level workers; and the growing presence of agronomists, winemakers, and other specialists, such as consultants (Heredia and Poblete, 2013; Maclaine Pont and Thomas, 2007, 2012). Additionally, the role of the vineyard contractor declined, thus weakening the link between his personal life and work (Poblete, 2012). At the same time, the hiring of seasonal workers increased, although working conditions did not improve and remained precarious (Fabio, 2010; Quaranta and Fabio, 2011).
Within this context, the relationship between wineries and vineyards intensified (Maclaine Pont and Thomas, 2007), and the control that wineries had over vineyards increased drastically (Brignardello, 2012; Maclaine Pont and Thomas, 2012). As a result, small and medium-sized vineyards in this region had to develop diverse ways in the context of this quality turn.

Historically, this sector of small and medium-sized vineyards played a significant role within the local wine industry (Bocco, 2005). However, in recent decades, all of Mendoza's farmland of up to 25 hectares in size has shrunk in the High Mendoza River Area (Table 1). In 2008, these farms represented $18 \%$ of the total and only $14 \%$ of the total hectares of Mendoza (INDEC, 2009).

The Table 1 illustrates the diminishment in the number of small and medium-sized vineyards during the 20-year period between 1988 and 2008. Despite this phenomenon, this sector has not completely disappeared. Identifying the ways in which these vineyards restructure labor within the context of this changing environment is the purpose of this study. First, we examine work performed by family members and then, we analyze that of non-family workers. For both types of work and workers, we focus on what we consider to be key dimensions of a sociological analysis of agricultural labor: type of hiring, forms of compensation, labor division, and gender.

\section{Family and work in small and medium-sized vineyards}

The role of the family in agricultural labor varies due to general transformations in the sector, changes in the overall agricultural industry, as well as family compositions, backgrounds, and life-cycles (Craviotti, 2000). Furthermore, broader social changes, such as the shrinking size of the rural population and agricultural labor sector, impact this role.

We have identified three types of typical family participation in small and medium-sized vineyards. Each type involves different family members with diverse forms of engagement and compensation for their work. The "Minimal family contribution" type describes when only one member (usually the grower's wife) participates in what are considered as secondary activities in the vineyard's operation. These activities include going to the bank and purchasing agricultural supplies. Usually, the family member who does these things is not paid because this work is perceived as a way of collaborating with the family business.

The next type is what we call "Restricted family contribution", which refers to two different circumstances. The first one involves the temporary participation of family members in manual labor, such as during short periods of high labor demands (e.g. the harvest season). The second circumstance is when family members intervene sporadically in the management and supervision of other workers, but do not engage directly in manual labor. In both cases, family members are not paid, although they receive other benefits (e.g., childcare and the authorization to borrow tools, etc.).

Finally, we identify a third type of family participation we call "Wide family contribution". It refers to when family members, usually the grower's children, participate directly in 
Table 1. Evolution of the number of farms and their area in hectares in the High Mendoza River Area and in the province of Mendoza as a whole, from 1988 to 2002 and from 2002 to 2008. Source: INDEC, 1988, 2002 and 2009.

Tableau 1. Évolution du nombre d'exploitations agricoles et de leur surface en hectares dans la zone amont de la rivière Mendoza et dans l'ensemble de la province de Mendoza, de 1988 à 2002 et de 2002 à 2008.

\begin{tabular}{|c|c|c|c|c|c|c|c|}
\hline & & \multicolumn{2}{|c|}{ Total } & \multicolumn{4}{|c|}{ Farms } \\
\hline & & $1988-2002$ & $2002-2008$ & $1988-2002$ & $2002-2008$ & $1988-2002$ & $2002-2008$ \\
\hline \multirow[b]{2}{*}{ High Mendoza River Area } & Farms & -1130 & -752 & -1220 & -755 & 32 & 10 \\
\hline & Hectares & 12,281 & 2447 & -4750 & -3698 & 17,028 & 6145 \\
\hline Province of Mendoza & Farms & -2593 & -6312 & -4896 & -5545 & -24 & -245 \\
\hline
\end{tabular}

all areas of the vineyard's operation. Their tasks may include, among others, manual labor, machinery operation (e.g., tractors), and the management and supervision of other workers. These family members usually receive a fixed monthly salary and are recognized as important contributors to the vineyard's operation.

Within each of these family participation types, we notice a division of labor along gender lines. While the males perform the manual tasks and operate the machinery, the females manage service payments and the stocking of supplies. This gender division creates great inequality in terms of decisionmaking regarding the vineyard's operation and the compensation family members receive for different responsibilities.

In sum, we recognize that despite the ongoing quality turn, family participation in the vineyard's operation is not fading away. Rather, family involvement takes on increasingly heterogeneous forms. In the next section, we focus on nonfamily workers in this sector.

\section{Non-family workers in small and medium- sized vineyards}

Based on our fieldwork, we identified two types of nonfamily workers in small and medium-sized vineyards in the High Mendoza River Area: permanent and temporary workers. Within the category of permanent workers, we identified two subcategories: the vineyard contractor described earlier and the worker who receives a monthly salary and is supervised by the grower. While the contractor's role has declined in this sector, as we mentioned previously (Poblete, 2012), it is still present in some small and medium-sized vineyards and in these cases, the link between the contractor's home and work lives is not broken.

With respect to temporary workers, their status varies according to the tasks they perform. Those who take part in harvesting and pruning, for instance, are considered key workers. Alternatively, those who perform the task of tying are considered peripheral workers.

One of the reasons why temporary workers who engage in harvesting and pruning are awarded higher status is because these tasks are part of the new turn to quality movement. It is also important to highlight that winegrape growers have generally recruited a large number of them because the harvesting period is short, and the machinery is difficult to operate. In terms of recruitment methods for harvest workers, we find that as in other wine grape producing areas, there exists a variety (Fabio, 2010; Neiman and Blanco, 2005). For example, winegrape growers may hire workers directly; appeal to a contractor (locally called a "cuadrillero"); use an employment agency; or, if the grower has a vineyard contractor, rely on his family members. No matter the recruitment method used to hire temporary harvest workers, the level of remuneration is always tied to individual productivity levels. That is, harvest workers must work extra hard to meet quality demands and maintain their speed in order to earn the same amount of money as before the quality turn began.

However, recent changes have led some small and medium-sized vineyards to outsource harvest labor to wineries. In other words, the winegrape growers pay the wineries to provide the workforce, tools, and training, as well as supervise the labor. This is the first time in local history that small and medium-sized vineyards have outsourced such an important part of their work, and it may become a trend leading to a decrease in their autonomy.

In addition to hiring temporary workers for the harvest season, small and medium-sized vineyard growers recruit those with great expertise in pruning. These workers tend to be the grower's neighbors or acquaintances and sometimes, they are even retired farm workers. With the quality turn, pruning has become regulated by agronomic guidelines, thus slowing the process at which workers previously performed this task and causing wineries to exert greater control over the practice. In response to these changes, the grower seeks to recruit the same workers each year for consistency, yet the earnings these workers receive are still dependent on their level of productivity (i.e., the amount of work they accomplish per row).

For the task of tying grape vines, growers prefer to hire female temporary workers. They argue that "feminine characteristics" (e.g. delicacy) are most beneficial for this task. As in the case of temporary workers hired for pruning, winegrape growers tend to recruit people they already know to do tying. However, unlike in the case of hiring practices for pruning, the quality turn has not affected the qualifications sought after in temporary workers who do tying. In other words, females have always been given preference for this type of work and therefore, the labor division along gender lines is not new and does not signify a feminization of the workplace.

The following question still remains: how does a grower manage to successfully recruit temporary workers under 
working conditions that require them to work extra hard to meet the expectations embedded in the quality turn without the guarantee of stable employment and a fixed salary in return? He relies on strong relationship ties with the community, as well as his friends and extended family members. In this way, the grower saves time and money spent on recruitment, faces less risk of worker turnover, and is able to simplify the organization and management of the vineyard's operation.

Another non-family worker found in today's small and medium-sized vineyards is the agricultural engineer. Since the quality turn began in the agricultural industry, other sectors have relied on engineers in their operations, but this is only a recent phenomenon in the sector under study (Heredia and Poblete, 2013; Maclaine Pont and Thomas, 2007, 2012). In fact, we observe that the agricultural engineer is hired right after winegrape growers adopt quality control measurements in their operations. The agricultural engineer is paid a fixed monthly salary, but there is not a formal labor relation between him and the grower.

In summary, we find a wide range of forms in which nonfamily workers participate in small and medium-sized vineyards in the High Mendoza River Area. Among permanent workers, we discover an updated version of traditional figures, such as the vineyard contractor, along with regular workers. However, we also notice that the reliance on temporary workers, particularly ones with more skills, is increasing. At the same time, we see no improvement in the recruitment and working conditions, nor in the salary, for these workers. Thus, overall, winegrape growers incorporate elements from the new system while maintaining some from the old, including those of unstable and precarious working conditions.

\section{Conclusions}

Through examining the social organization of labor in small and medium-sized vineyards after the local quality turn began, we notice that this agricultural sector maintains a certain structure that tends toward traditional work relationships (Newby, 1983). This involves establishing more personal relationships between the grower and workers than in any other labor sector. As a result, these winegrape growers face less difficulties in recruiting and maintaining non-family workers. While this social structure may appear to be in conflict with the increased value placed on technical skill and expert knowledge in wine grape cultivation, as well as the incorporation of technological innovations, we do not believe this to be the case. On the contrary, we discover that small and mediumsized vineyards incorporate these modern values into their traditional social framework and labor practices.

With regard to the grower's family members, we notice that overall, the quality turn does not imply the disappearance of this labor force. Rather, their work may entail more managerial responsibilities. In terms of non-family workers, we notice that even while vineyard tasks increase and require more skill as a result of the quality turn, these workers are still paid according to their level of productivity. This situation runs counter to the argument that more skilled workers should be compensated with a fixed monthly salary.

In conclusion, we argue that with the occurrence of quality turns in agriculture, small and medium-sized vineyards have managed to continue successfully cultivating wine grapes in a restructured system. This success has entailed updating old elements and implementing new tasks, workers, and modes of management. Nevertheless, while these vineyards have been incorporated into this modern agricultural system, they do not always share in the benefits of the global market to which they contribute and belong. Additionally, the increased social differentiation within this sector, which has resulted from the need to adapt to a restructured system and to the quality turn, may grow in the future. This could generate more inequality between small and medium-sized vineyards in a local context.

\section{References}

Alvaro M. 2012. Impactos de la modernización en los chacareros frutícolas del Alto Valle rionegrino. Mundo Agrario 12(24).

Azpiazu D, Basualdo E. 2001. El complejo vitivinícola en los noventa en la Argentina, potencialidades y restricciones. Buenos Aires: FLACSO.

Bendini M, Pescio C. 1996. Trabajo y cambio técnico. El caso de la agroindustria frutícola del Alto Valle. Buenos Aires: La Colmena, $287 \mathrm{p}$.

Biénabe E, Vermeulen H, Bramley C. 2011. The food "quality turn" in South Africa: an initial exploration of its implications for smallscale farmers' market access. Agrekon 50(1): 36-52.

Bocco A. 2005. Trama Vitivinícola: Reconfiguración de actores y transformaciones estructurales. IV Jornadas Interdisciplinarias de Estudios Agrarios y Agroindustriales, 9 al 11 de Noviembre 2005. Buenos Aires: Facultad de Ciencias Económicas, Universidad de Buenos Aires.

Bocco A, Neiman G. 2001. Mercado de calidad y trabajo. El caso de la vitivinicultura argentina. V Congreso Nacional de Estudios del Trabajo. Buenos Aires: ASET.

Bonanno A, Cavalcanti J. 2011. Globalization, Food Quality and Labor: the case of grape production in north-eastern Brazil. Internacional Journal of Sociology of Agriculture y Food 19(1): 37-55.

Brignardello M. 2012. Reestructuración, Calidad y Relaciones Sociales. Transformaciones en el vínculo productor vitivinícola - agroindustria en Mendoza, Argentina. Agrária 16: 95-120.

Buttel FH. 1997. Some observations on agro-food change and the future of agriculture sustainability movements. In: Goodman D, Watts M, eds. Globalising food. Agrarian questions and global restructuring. London: Routledge, pp. 344-365.

Collado P. 2006. Desarrollo vitivinícola en Mendoza - Argentina. Apuntes sobre su origen. Trabajo y Sociedad. Indagaciones sobre el empleo, la cultura y las prácticas políticas en sociedades segmentadas $8(2)$.

Craviotti C. 2000. Los procesos de cambio en las explotaciones familiares pampeanas: tendencias en el trabajo agrario y dinámicas familiares. Cuadernos de Desarrollo Rural 45: 69-89.

Fabio J. 2010. Regulación social de la transitoriedad. El mercado de trabajo en la producción de uvas en Mendoza, Argentina. Cuadernos de Desarrollo rural 7(64): 31-55.

Friedmann H. 1980. Household production and the national economy: concepts for the analysis of agrarian formations. Journal of Peasant Studies 7(2): 158-184.

Gras C, Hernández V. 2009. La Argentina rural. De la agricultura familiar a los agronegocios. Buenos Aires: Biblos, 289 p.

González P, Parga-Dans E. 2017. 'Marketing quality' in the food sector: towards a critical engagement with the 'quality turn' in wine. Geoforum 85: 5-8. 
Goodman D. 2003. The quality 'turn' and alternative food practices: reflections and agenda. Journal of Rural Studies 19: 1-7.

Henson S, Humphrey J. 2010. Understanding the complexities of private standards in global agri-food chains as they impact developing countries. Journal of Development Studies 46(9): 1-22.

Heredia M, Poblete L. 2013. La estratificación socio-laboral en un caso de globalización exitosa: la vitivinicultura mendocina (19952011). Mundo Agrario 14(27). La Plata.

Hervieu B. 1996. Los campos del futuro. Madrid: Ministerio de Agricultura, Pesca y Alimentación.

INDEC. 1988. Censo Nacional Agropecuario. Buenos Aires.

INDEC. 2002. Censo Nacional Agropecuario. Buenos Aires.

INDEC. 2009. Censo Nacional Agropecuario 2008-Resultados Provisorios. Buenos Aires.

INV (Instituto Nacional de Vitivinicultura) 2016. Base de dato electrónica. http://www.inv.gov.ar. [2016/11/28].

Lara Flores SM. 1998. Nuevas experiencias productivas y nuevas formas de organización flexible del trabajo en la agricultura mexicana. México: Juan Pablos Editor Procuraduría Agraria, $302 \mathrm{p}$.

Law 23.154. 1984. Explotación de viñas y frutales. Official bulletin of Mendoza.

Long N. 1996. Globalización y localización: nuevos retos para la investigación rural. In: Grammont $\mathrm{HC}$, Tejera Gaona H, eds. La sociedad rural mexicana frente al nuevo milenio. México: Plaza y Valdez, pp. 35-74.

Maclaine Pont P, Thomas H. 2007. How the vineyard came to matter: grape quality, the meaning of grapevines and technological change in Mendozás wine production. Universum 22(1): 218-234.

Maclaine Pont P, Thomas H. 2012. The sociotechnical alliance of Argentina quality wine: how Mendozás viticulture functions between the local and the global. Science, Technology and Human Values 37(6): 627-652.

Maertens M, Swinnen J. 2015. Agricultural trade and development: a value chain perspective. WTO Working Paper ERSD. Switzerland: World Trade Organization. Economic Research and Statistics Division.

Marsden T. 1997. Creando un espacio para la alimentación. Las características del desarrollo agrario reciente. In: Goodman D, Watts MJ, eds. Globalising and food.Agrarian questions and global restructuring. London: Routledge, p. 169-191.

Marsden TK, Cavalcanti J, Ferreira Irmao J. 1996. Globalisation, regionalisation and quality: the socio-economic reconstitution of food in the San Francisco Valley, Brazil. International Journal of Sociology of Agriculture and Food 5(96): 85-114.

McDermott G. 2007. The politics of institutional renovation and economic upgrading: recombining the Vines that bind in Argentina. Politics \& Society 35(1): 103-143.
Neiman G. 2003. La "calidad" como articulador de un nuevo espacio productivo y de organización del trabajo en la vitivinicultura mendocina. In: Bendini M, Cavalcanti J, Murmis M, Tsakoumagkos $\mathrm{P}$, eds. El campo en la sociología actual: una perspectiva latinoamericana. Buenos Aires: La Colmena, p. 291-314.

Neiman G. 2010. Estudio sobre la demanda de trabajo en el agro argentino. Buenos Aires: Ediciones CICCUS, 328 p.

Neiman G, Blanco M. 2005. Estructura de la ocupación en establecimientos vitivinícolas de la provincia de Mendoza. Revista Aset, $\mathrm{N}^{\circ}$ 7, Buenos Aires.

Newby H. 1983. La sociologia rural institucionalizada. In: Newby H, Sevilla Guzmán E, eds. Introducción a la Sociología Rural. Madrid: Alianza Editorial, p. 13-37.

Overton J, Murray WE, Banks G. 2012. The race to the bottom of the glass? Wine, geography, and globalization. Globalizations 9(2): 273-287.

Pedreño A. 1999. Taylor y Ford en los campos. Trabajo, género y etnia en el cambio tecnológico y organizacional de la agricultura industrial murciana. Sociología del trabajo 35: 25-56.

Poblete L. 2012. De trabajadores inamovibles a trabajadores móviles. El caso de los contratistas de una region vitícola de Mendoza, Argentina (1995-2010). Cuadernos de Relaciones Laborales 30 (2): 519-539.

Poblete L. 2013. Reconversión agroindustrial, recomposición de las relaciones laborales y reestructuración del territorio. La vitivinicultura mendocina entre 1995 y 2010 (Argentina). Eutopía 4: 11-24.

Quaranta G. 2003. Reestructuración, organización del trabajo y mediería en la producción lechera de la pampa húmeda bonaerense. Buenos Aires: Informe de Investigación $n^{\circ} 13$ CEIL CONICET.

Quaranta G, Fabio F. 2011. Intermediación laboral y mercados de trabajo en agriculturas reestructuradas: el caso del Valle de Uco, Mendoza, Argentina. Región y Sociedad XXIII(51): 193-225.

Raftery D. 2017. Producing value from Australia's vineyards: an ethnographic approach to 'the quality turn' in the Australian wine industry. Journal of Political Ecology 24: 342-367.

Richard Jorba R. 2003. El mercado de trabajo vitivinícola en la provincia de Mendoza y los nuevos actores. El contratista de viña: aproximación a un complejo sistema de empresarios y trabajadores, 1880-1910. Revista Interdisciplinaria de Estudios Agrarios 18: 5-37.

Trienekens J. 2011. Agricultural value chains in developing countries. A framework for analysis. International Food and Agribusiness Management Review 14(2): 51-82.

Trienekens J, Zuurbier P. 2008. Quality and safety standards in the food industry, developments and challenges. International Journal of Production Economics 113: 107-122.

Ufkes F. 1993. Trade liberalization, agro-food politics and the globalization of agriculture. Political Geography 12(3): 215-231.

Cite this article as: Brignardello M. 2018. Changes and continuities in agricultural work: the case of small and medium-sized vineyards in Mendoza, Argentina. Cah. Agric. 27: 35007. 